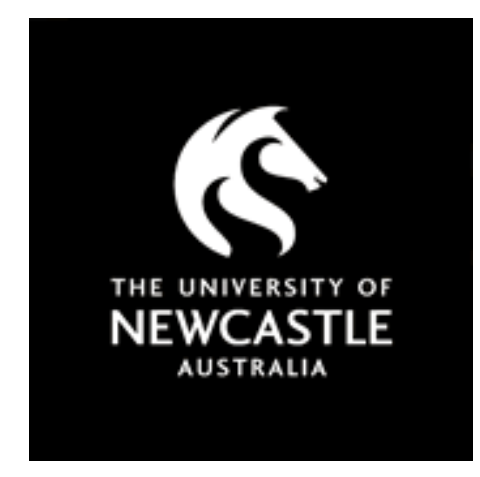

NOVA

University of Newcastle Research Online

nova.newcastle.edu.au

Leahy, Terry; Goforth, Monika 'Best practice for rural food security projects in Southern Africa?’, Development in Practice Vol. 24, Issue 8, p. 933-947 (2014)

Available from: http://dx.doi.org/10.1080/09614524.2014.969196

This is an Accepted Manuscript of an article published in Asia Pacific Business Review on 17/11/2014, available online:

http://www.tandfonline.com/10.1080/09614524.2014.969196

Accessed from: $\underline{\text { http://hdl.handle.net/1959.13/1297148 }}$ 


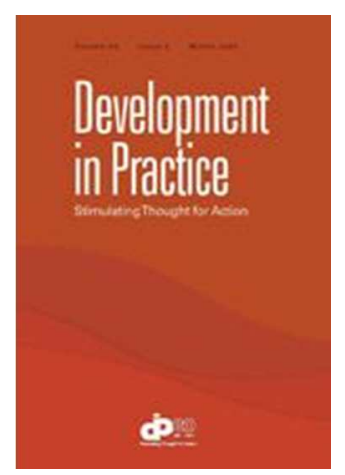

\section{Best practice for rural food security projects in Southern Africa?}

\begin{tabular}{|r|l|}
\hline Journal: & Development in Practice \\
\hline Manuscript ID: & CDIP-2013-0019.R1 \\
\hline Manuscript Type: & Article \\
\hline Keywords: & $\begin{array}{l}\text { Aid effectiveness < Aid, NGOs < Civil society, Food security < Environment } \\
\text { (built and natural), Poverty reduction < Labour and livelihoods, Region: } \\
\text { Sub-Saharan Africa }\end{array}$ \\
\hline Abstract: & $\begin{array}{l}\text { It has been widely believed that commercialization is the solution to food } \\
\text { insecurity in rural Africa. Project designs have attempted to set up } \\
\text { agricultural cooperatives and encourage entrepreneurial farmers. Yet the } \\
\text { problems revealed in the fifties are still widespread. In a counter } \\
\text { perspective, some have argued for the relevance of subsistence and low } \\
\text { input agriculture. This article examines three NGO projects in South and } \\
\text { South Eastern Africa which prioritize food security through household } \\
\text { subsistence, using low input technologies - along with encouragement to } \\
\text { produce a surplus for cash. We look at what these projects share and why } \\
\text { their strategies work. }\end{array}$ \\
\hline
\end{tabular}




\title{
Best practice for rural food security projects in Southern Africa?
}

\author{
Dedicated to the memory of Elijah Kyamuwendo \\ It has been widely believed that commercialisation is the solution to food insecurity in \\ rural Africa. Project designs have attempted to set up agricultural cooperatives and \\ encourage entrepreneurial farmers. Yet the problems revealed in the fifties are still \\ widespread. In a counter perspective, some have argued for the relevance of \\ subsistence and low input agriculture. This article examines three NGO projects in \\ South and South Eastern Africa which prioritize food security through household \\ subsistence, using low input technologies - along with an encouragement to produce \\ a surplus for cash. We look at what these projects share and why their strategies \\ work.
}

Key Words: Subsistence; food security; projects; Africa; low input

\section{Food security and low-input subsistence agriculture}

The dominant message on development for rural Africa has been that commercial agriculture is the solution to food insecurity problems (Payer 1979; Williams 1996). An example of the intention and rationale is the Ugandan government's 'Plan for Modernisation of Agriculture'. The objectives were to 'increase incomes and improve the quality of life of poor subsistence farmers, improve household food security, provide gainful employment' (MAAIF 2000: vi). The mission was 'eradicating poverty by transforming subsistence agriculture to commercial agriculture' (MAAIF 2000: vi). The intention was that farmers would orient most of their production to the market to gain higher incomes. Instead of providing their own food through their farms, they would specialise in profitable commercial crops and use the income to purchase food. Increased productivity through technology would produce more with less land and labour, keeping 'downward pressure on real food prices' for both rural and urban poor. An expansion of the food market coming from lower prices and increased production was also expected to provide capital for business ventures, stimulating economic activity in rural areas (MAAIF 2000: vi-vii).

This argument has been promoted by the World Bank, African governments and most international charities (for example Department of Agriculture 2002; FARA 2006; Magadzi 2008; MAAIF 2000; Parliamentarians 2006). It is accepted by many government workers in agricultural extension (Leahy 2011) and is a stock in trade of much development writing. A recent statement gives a sense of how this discourse is expressed today:

To retain viable livelihoods, small producers in many areas need to move from a focus on production for home consumption and occasional marketing of surpluses to production for the market, i.e. to responding to the ever 
increasing demands of the market. (Chipeta, Christoplos and Katz 2008: 8; see also Leavy and Poulton 2007; Wolter 2008; Maxwell and Fernando 1989; Webersik and Wilson 2008)

Along with this go two models for projects. In the 'community group entrepreneurial project' (Leahy 2009; Leahy 2011) between twenty and forty villagers are selected for a commercial enterprise on land allocated to the project. They are supplied with inputs and equipment. They are meant to grow and market their produce, or to engage in some value adding process. They are to jointly engage in production, and manage their joint income to fund their ongoing expenses. A second common design is the 'lead farmer' project (Alinyo and Leahy 2012; Danida 2005). A likely farmer is selected to pioneer a new commercial strategy. They are supplied with inputs, training and equipment to model the strategy for others.

Yet despite more than forty years of this approach, the outcomes have been less than encouraging. Problems revealed in the fifties are still endemic. Deficiencies of total calories, protein, vitamin A and iron amount to malnutrition, stunting up to half the children in many of these countries (Barkworth and Harland 2009; Department of Agriculture 2002; Japan Association 2008). There are fuel wood shortages and deforestation, soils that are packed down hard from overgrazing, crop yields that fall constantly after initial clearing and a failure of the poor to use fertiliser (Japan Association 2008; Marenya and Barrett 2007). For example in Tanzania, only $15 \%$ of farmers are using fertiliser and crop productivity is 1.7 tonnes per hectare, compared with yields of 3.5 to 4 tonnes that are possible (Wolter 2008: 14). The environmental and productivity effects of poor agricultural techniques are compounded by high rates of population growth and smaller plot sizes (Marenya and Barrett 2007).

The project designs associated with commercialization are problematic. Community group entrepreneurial projects fail soon after the professionals depart. Conflicts within the group and extreme poverty make it hard to save and share money. Poor education makes it difficult to maintain the commercial equipment or the marketing and the production strategy. Community jealousy cements this disaster with thefts and vandalism (Leahy 2009; Leahy 2011; Marais and Botes 2007). Projects using the lead farmer model may have good outcomes for the chosen farmers. But they make no impact on rural poverty. The education required to run the commercial strategy and the funding required to get started are not available to most. There is little motivation to spread this model to others. Poorer local people view the success of the lead farmer as a function of their initial wealth and the unfair advantage the project has given them (Alinyo and Leahy 2012; Danida 2005).

Opposing this dominant perspective, some argue for the relevance of 'subsistence' and low input agriculture (Bryceson 2000; De Janvry and Sadoulet 2011; Pretty 1995). This article will address the context of Southern and South Eastern Africa. What is suggested here is not a global panacaea. Culture and land holding patterns make this solution particularly apt in this region and disqualify it where all this is quite different. Nevertheless, the pressure to find commercial solutions is universal and the tactics recommended here have parallels elsewhere (Wright 2008). The term 'subsistence' is used here in its strictly economic sense. It means that agricultural production is for use. It is the opposite of agricultural production which is for cash for sale - which is here referred to as 'commercial' agriculture. These are meant as 
neutral economic categories. 'Subsistence' should not be assumed to connote unproductive, unscientific and traditional.

The continuing presence of subsistence agriculture despite a sustained ideological and economic attack is one argument for its relevance (Shackleton, Shackleton and Cousins 2001). It makes sense for households that own some land (often under communal title) and are sustaining themselves through a 'multiple livelihoods' strategy. They can grow much of their own food without using their scarce cash. Continuing unemployment provides the time necessary. The unpredictability of the food market makes an assured subsistence better than being caught out if prices soar. In promoting commercialization, farm gate prices for staples are often compared to farm gate prices for commercial crops (for example Tschirley and Kabwe 2007). Yet it is the retail price of staples that is relevant. A high retail price for staples can make growing them a more reliable route to household food security than growing a cash crop - if they are eaten rather than being sold.

A strategy of full commercialization implies that African smallholders could grow enough on their land to make a viable living - making enough money to pay for all their food and their other needs. This is somewhat unlikely, as the land available for dryland cropping is usually one or two hectares and rarely more than three hectares per household (Rural Poverty Portal 2012). Up to a half of the rural population is struggling to provide sufficient carbohydrate production on the fields they have available to them. These small fields are unlikely to be able to produce enough to pay for annual food needs, while they might just produce sufficient food for the household to eat. They do not allow economies of scale and the use of farm machinery. Bad roads and poor market access make it almost impossible to get a good price. Quality control requirements are well beyond the levels of education and the capital and infrastructure possibilities of these farmers (Timmer 2005).

Domestic factors are also relevant. It is difficult to store the money from the harvest to buy food later, given the immediate needs of the family and the pressures to lend money. Better to have a household storage of subsistence crops. Men are quite likely to dominate the marketing of farm produce, whoever is doing the work. Better for women to produce for subsistence rather than depend on their husbands to store the income from the harvest (Alinyo and Leahy 2012; Barkworth and Harland 2009).

All this leads us to the argument for eco-agriculture, low input solutions. If food security is to be based on subsistence, the agricultural system being used cannot depend on reliable and timely injections of inputs bought with cash in the market. At the time when households most need to buy seeds, pesticides, fertilisers, tractor hire and the like, they will be quite likely to be short of cash. A low input system makes sense because it is not premised on harvest sales supplying the cash for inputs for the next year. What is required is an integrated multipurpose low input agriculture (Jones and DuPreez 2008; Leahy 2009; Mollison 1988). Legume trees and vines produce fuel wood, mulch and fodder and fertilise soils. Small livestock produce animal protein and manure for compost. Tanks, ponds and contour bunds hold water. Fruit and nut trees yield food for livestock and the family. Vegetables are complementary to cropping or are grown in gardens around the house. Seeds are saved for the next harvest and household supplies are preserved for the dry season. Root crops and plantains provide year round carbohydrates to supplement cereals. Production of 
cereals using organic methods (zero tillage; contour bunds; mulch; compost; legume intercrops) can multiply yields by a factor of four - to up to 4 tonnes per hectare (Phiria et al. 2004; Pretty 1995).

\section{The 'Food Security Outreach' model}

This article considers a model of rural development work which fits the above analysis. The three organizations to be examined prioritize subsistence production using low input technologies. They also break decisively with dominant models for project design. We are arguing that this 'Food Security Outreach' model seems likely to be best practice for food security projects in rural Southern Africa. We will be looking at three organizations.

- The first of these is TSURO in the Chimanimani district of Zimbabwe. This operates in twenty two of the twenty four wards of a district with 120 thousand people. The data for this organization is the most extensive, consisting of interviews with twenty one staff from the project, as well as interviews with thirty six beneficiaries. This data was supplemented by participant observation including farm visits, attendance at a community mediation and an annual planning meeting of TSURO staff. We also organized a small survey of 25 beneficiaries, which was conducted independently of the earlier interviews and with a cohort composed of five chosen from each of five districts.

- The second organization is KULIKA in Uganda. This organization carries out work in a variety of rural communities throughout south eastern Uganda. The data for this organization comes from their various publications and from interviews with two of the management staff, Elijah Kyamuwendo and Albert Obukulem. There was also a field trip to their rural and to their urban headquarters.

- The third organization is Is'Baya which operates in the Eastern Cape villages of South Africa. The management team is dispersed through various provinces of South Africa, although members have connections with the Eastern Cape through their personal biographies. The data here comes from their publications and from an interview with Rose Du Preez, who works on their agricultural strategies. It is also from their presentation at a conference in Eastern Cape on rural development.

Aspects of the food security outreach model will be illustrated with examples from each NGO.

These three projects were chosen by elimination. Extensive field work in South Africa combined trips to projects with agricultural officers in four different provinces, attendance at a conference hosted by a Government/University partnership for rural development at Walter Sisulu University in Eastern Cape, time spent at the University of Fort Hare in Alice, with departments specialising in rural development research, and field work in two villages where numerous projects had been attempted - one in Limpopo and the other in North Western Province. In Uganda, time was spent with academics studying agricultural projects from Makerere university and there were 
also long discussions with agricultural officers responsible for implementing government policies in Kapchorwa in the east of the country. Projects around Katete in Zambia were observed through a month of field work. Projects associated with the Namibia Polytechnic were accessed through a visit to that university and discussions with staff involved in rural development issues. In addition Terry Leahy taught African extension officers from 2003 to the present day in a Masters program at the University of Newcastle, speaking to them at length about their experiences in the field in countries such as Malawi, South Africa, Namibia, Lesotho, Kenya, Nigeria, Uganda and the Cameroons.

In all of this period, very few projects were encountered or described that did not in one way or another conform to the dominant models specified above. Almost all projects stressed commercial solutions to food insecurity and were organized to set up an entrepreneurial community group or give support to leading farmers to try out a commercial strategy. It was equally apparent that very few of these commercial projects were effective in the long term.

In other words, the projects chosen for discussion here are some of the few that we have encountered that depart from these dominant models. Their resemblance to each other was discovered, rather than being an artefact coming about through choosing three similar projects to begin with. The Is'Baya project was discovered through a presentation at Walter Sisulu University in Eastern Cape. The KULIKA project was presented at an international permaculture conference in Malawi in 2009 and the TSURO project was represented at that same event. Research to follow up these initial discoveries took place in subsequent years.

In explaining these projects, we make use of quotations from the interviews and from the literature produced by these projects. In the case of TSURO, the basic framework with which this organisation operated was confirmed by numerous interviewees and was not contradicted by any of them. This evidence was supplemented by field experience with the beneficiaries, farm visits and attendance at various events organized by TSURO. We also examined written documents at the TSURO headquarters, as well as reports and photographs of TSURO activities. In the case of KULIKA, the two interviewees gave a similar report of the working of the organization, which was confirmed by the promotional literature made available to the researchers. This included quotations from beneficiaries and accounts of particular interventions. The agricultural strategies being promoted were also evident at their rural headquarters. In the case of Is'Baya, an extensive interview was conducted with one of their leading organizers, who backed up the account of the organization which had been presented by other organizers at the preceding conference a year earlier. The authors were also given access to a report which detailed the activities and rationale of the organisation and their methods of giving assistance. A newspaper format journal also gave accounts of local activities and included quotations from beneficiaries and photographs of the sites in question. All of this documentary material confirmed the analysis given by the key interviewee.

\section{The substance of the assistance}

The three organizations all attempt to develop food security through subsistence farming using low input agriculture. This is the substance of their assistance. 


\section{Subsistence plus surplus}

The de facto orientation of all three organizations is to make the first priority household food security through subsistence. They also appeal to aspirations for increased cash income by suggesting that households start by increasing food production for their own use and then go on to market the surplus. A TSURO beneficiary produced the formula which is at the heart of this strategy:

... before then I lacked some certain skills and knowledge on how to farm. But through TSURO I had to attend workshops and I would implement those skills that I was trained on. I have also improved in my yield from the farm. I am now getting enough to feed my family, and surplus to sell.

A member of the Machete community nutrition garden, assisted by TSURO, explained the benefits of their initiative:

All this allowed our children to eat till they were full. And this allowed them to become healthy.

TSURO advises farmers on how to increase their yield using permaculture strategies. They also give advice on how to get a higher price from the surplus and engage beneficiaries in specific money making projects, such as producing honey for sale.

Elijah Kyamuwendo, the CEO of Kulika in 2010, explained its origins in 1981, and their decision to concentrate on food security issues, given the hunger in rural areas. Their research in 1992:

... proved that, there was enough food resources unutilised and yet they can cause great effect towards people having food enough to eat and having some surplus to sell.

The project shows people how they can use the materials they have to hand and gradually improve their farming output. For example, the poorest farmers might be encouraged to store water by using discarded plastic containers, by digging a hole or a contour bund. By increasing their agricultural production through these methods they could sell some surplus and buy polythene for a pond. Going further they might buy concrete for a tank:

If you are in a community, members will look at where you are. Then after that we start talking to people. Why don't you visit this person, she or he has lining it with the polythene. This one has lining with polythene, this one has made a concrete pond! So they see the progression. So we show you where you can go if you work hard.

The project attempts first to increase the subsistence production of the poorest using the materials they already have. It also promises a surplus. With that, an increasing ability to purchase inputs to their farming, ending up with a top level commercial farm. This promise breaks through the stigma associated with subsistence. 
We can see this complex interrelationship of subsistence and commercial strategies also appearing in the reports produced by Kulika. One farmer spoke exclusively of the food security benefits:

The training I acquired from Kulika has helped me to learn how to use compost and led to improved yields of my crops. My expenditure on medical bills has greatly reduced due to reduced incidences of disease in my family, especially among children due to availability of quality foods like vegetables. Children look healthier ... (Kulika 2009: 6)

Another began by talking about his larger harvests and healthier children but went on to say:

... as you can see my crop fields. I can see money all around. (Kulika 2009:

9)

The central strategy of the Is'Baya organization in South Africa is to offer fruit tree seedlings to housheholders to plant on their own residential land. These homestand plots are generally used for grazing a goat or sheep and for growing a small quantity of maize for family consumption. The aim of the project is to supplement this current agriculture by providing families with abundant fruit. The project sells the trees at a subsidized price and provides advice on how to establish and care for them. They distribute varieties that will produce marketable fruit to allow a small additional income. The effect is to greatly increase the nutritional value of food grown for household consumption.

As Rose Du Preez says, villagers come to this package with a variety of motivations:

And some think it would be nice to have some mangoes and guavas and so on, and that's the thing ... others immediately see the opportunity that they could make money.

She explained the way that they encouraged householders to plant a suite of varieties to ensure a continuous supply of vitamins; mangoes, citrus and guavas fruiting at different times for maximum nutritional impact. The centrality of food security and household subsistence production is promoted in the Is'Baya literature:

The initial objective is to increase food production by each household to ensure food and nutritional security. Even modest gains in output by very large numbers of small farmers, when translated into improved diets, would have a major impact in reducing rural hunger and poverty and an immediate improvement in health. (Jones and DuPreez 2008: 12)

\section{Low input agriculture}

All three projects recommend 'low input' agriculture (Pretty 1995). A subsistence strategy necessitates low input agriculture because there is no expectation of profits from agricultural sales. 
The TSURO project promotes low input agriculture as 'permaculture'. Johannes Mufakose from the TSURO centre describes the activities that they are engaged in with farmers in one ward of the district:

And these farmers are involved in different project areas that include agroforestry and rainwater harvesting. They are also involved in small livestock management, like poultry, goats, guinea fowl, just to mention but a few. And also, they are also involved in watershed management and water source protection. And also involved in permaculture garden design.

Major Mareni, a beneficiary from one of the dryer areas of the Chimanimani district explains the way his farming practices have been helped by TSURO:

I started putting in the terraces, because when the land is not terraced, usually the moisture runs away, taking the soil away and leaving the soil without nutrients. I put in a lot of organic stuff, manure from the cattle kraal. I had to put in a lot of compost to enrich the soil. Now I have joined the permaculture. They taught us how to make good compost. We have started planting a lot of trees, we look after chickens and turkeys, goats, cattle. Now we are getting the manure from the animals to put into the field.

We also interviewed Wilson Hodhera, who explained how his farm was running according to permaculture principles:

I do sustainable agriculture and organic farming only. I have quite a diversity of crops ranging from vegetables to fruits. These elements are related.

Elijah Kyamuwendo from KULIKA indicated that low input agriculture has always been their preferred option. People were going hungry because of the failure of local agriculture following the civil war, so they decided to promote organic solutions. $\mathrm{He}$ gave an account that stressed the economic logic:

So, the research looked at what can be done from the resources that are everywhere without bringing in new outside inputs and things where people say - 'but we can't afford that'. So we looked at the things that can be used from wherever you are, the natural resources that were at the disposal of the starving communities.

Is'Baya describes its agricultural strategy as 'conservation agriculture'. In an explanation of their project, they begin by noting the necessity to take care of the environment and go on to specify the characteristics of conservation agriculture as follows:

The key principles are ensuring the recycling and restoration of soil nutrients and organic matter and optimal use of rainfall through retention and better use of biomass, moisture and nutrients. (Jones and DuPreez 2008: 12) 
They clearly relate this strategy to the financial imperatives of food production for poor families, claiming that conservation agriculture cuts production costs (Jones and DuPreez 2008: 12). Few inputs are to be purchased because cover crops, manure, compost and management practices take the place of chemical fertilizers, herbicides and pesticides.

\section{The methods of assistance}

Along with the substance of assistance go a variety of methods, which are equally vital.

\section{Individual households, rather than entrepreneurial collectives}

All three organizations target individual households working on their own land. Rose Du Preez explained why Is'Baya abandoned the group project model:

Okay, we looked at the communal sites, not even at just ours but all other projects working on communal sites ... they just weren't working! We planted at eleven communal sites, of which not one is functional today. Government or funders come in and say, 'Okay! We've got funds! Who wants to plant trees?' So people see money, they say 'We want to!' So they plant trees and then today you work, and I work, and you don't work and so tomorrow I'm cross with you, so I don't work and then no-one works and the goats get in because no one closed the gate.

Accordingly, Is'Baya moved to providing fruit trees to be planted on people's own land. Yet they depended on some group processes. A beneficiary who wanted to start the project in their village would have to recruit twenty households, form a committee and collect money for the trees. These group processes rely for success on the framework which targets individual households:

Everyone, when it comes to the actual trees, they're my trees, and they're your trees. So I want it to work because if the village falls apart, okay.

An example explains how individualistic motivation works to improve outcomes:

One man takes me to his garden and he says, 'This tree, I'll leave here for always to teach people' (there's this little citrus tree), he says, 'I was digging this big hole and I got so tired so I dug a little hole. Is 'Baya won't see! They won't notice!' And then he said, 'And then I saw my other trees growing big. And these trees, I planted the next year in a big hole'. And then he saw. 'Is'Baya can't see, but I can see! (laughs). I cheated myself! (laughs) Because that tree cost me ten rand!'

TSURO and KULIKA likewise work with individual households to improve farming on their own land. Exceptions show the same principles. The Machete community garden was divided into individual household plots, with produce going to the household. The inputs donated by TSURO were poly pipe to bring water and fencing 
mesh for the whole plot. Neither of these required beneficiaries to pool money to maintain them. So there is no attempt to pool produce for sale and there is no need to pool profits to maintain equipment.

\section{No money paid for work to improve your own land}

None of these projects pay villagers to work on improvements to their own land. The example from Is'Baya above shows how this works. The beneficiary is working on his own land and finds that his failure to dig a large hole is his own problem.

An example from TSURO indicates that community working parties can also operate without payment. A village committee specified contour bunds as the kind of assistance they wanted from TSURO. Having accepted the project, TSURO took some villagers to look at contour bunds in use elsewhere. The local committee chose one farmer to be the first to receive a bund in their cropping field and all pitched in with labour to construct it, without payment. Later, the same process was repeated on the fields of other farmers, but without the necessity for further instruction from TSURO.

There is a common belief that projects in Africa will not work unless beneficiaries are paid (Leahy 2009). All three of these projects ignore this common wisdom in order to ensure that villagers are actually committed to the projects. They begin their work with the few who are willing to volunteer their labour and recruit as the fruits of this work become apparent.

\section{All invited}

The two dominant models for project design include members of a community selectively. There is a limit to who can be involved because commercial infrastructure costs considerable money. Instead, food security outreach projects work with subsistence and can invite everyone. Along with this goes a second key element these projects only respond to an initiative and felt need coming from the community; a need demonstrated by willingness to volunteer work.

Johannes Mufakose, one of the management team from TSURO, explained the initiation of the Machete irrigated community garden:

Out of the need that the area is dry. Out of that the group actually visited TSURO and presented their proposals to TSURO. TSURO will assess those village-based plans and see how they can intervene and support the group.

From the whole community which they service (the whole of the Chimanimani district), TSURO invites local people to form themselves into community groups and to nominate projects, which may get funding if TSURO thinks that the project makes sense. 
KULIKA makes a similar attempt to invite all members of a community to make improvements to their productivity. Albert described their package of suggestions like this:

Its a comprehensive basket. Where people are allowed to choose what to actually take and what they can take in bits.. Actually start with a contour, stabilise it. Put a vegetable. Then as you put the vegetable, we say that the chickens need a run. Because the chickens will destroy the vegetables. So it is a step by step build zone.

This approach has something for every class level in the community. It works with the very poor where they are at and gradually improves their situation, so they can pay for iputs after they begin to sell some surplus production. The whole community can be invited because KULIKA is not paying for expensive inputs.

Is'Baya is the same in making an effort to invite all members of a defined community (a rural village) to participate in their fruit project - rather than creating a project that can only be the vehicle of improvement for some households. What Is'Baya is offering is fruit trees provided at a subsidized cost, along with training in looking after them:

We put criteria in. We said, can't plant just one tree, we must plant in a year, a minimum of ten [per household] and we need in a village, a minimum of twenty households. And that we also need a village to elect out of those households who want to do it; to elect a committee. Because we can't talk to twenty households. So you form a committee.

The offer is made to all families in the village but the criteria for inclusion is demonstrated participation. News of the efficacy of this system spread, leading to further recruitment:

So the villages started growing and every year we would get more villages. Someone would come and sit in the meeting and then say 'Okay, actually I'm not from this village. I came from that village over there, you must come to my village.'

\section{Few material inputs}

These projects avoid expensive inputs. The emphasis is on training and consultation. When industrial inputs are provided, they are things like polypipe, cement or fencing mesh. Start up packages such as open pollinated seeds, small livestock or fruit trees, are sometimes donated. These are to be maintained and propagated further by beneficiaries, without the necessity for further cash inputs.

Major Mareni explained that on his farm, TSURO had assisted with educational input:

... the permaculture people took me for some exchange visits to see what others are doing. We get the knowledge of how to make compost, how to grow herbs, how to grow some vegetables. 
His farm now demonstrated a variety of small livestock, use of terracing with rock walls, a pond, numerous fruit trees, a variety of grain crops. As an example of similar strategies from KULIKA, Elijah responded to a question about chicken wire with a complex account. On the one hand, farmers who had a bit of money would be urged to buy chicken wire to fence in their poultry. Yet, for the poor they were advising the use of reeds. Living fencing was promoted to keep goats. Bundles of napier grass could be tied together to construct a fence. A pit was promoted to enclose pigs.

The bottom line is that subsistence production for food security cannot depend on the vagaries of the cash economy. So machinery which needs to be serviced by paid mechanics and operated with supplies of diesel is not a sensible donation. Nor are start up packages consisting of fertiliser and hybrid seeds - which have to be purchased again for the next crop.

\section{Bureaucratic democracy}

All three organizations maintain a professionally staffed centre which reaches out to the villages. They set up defined authority structures, involving local people in specified roles. This is 'bureaucratic' in relation to the defined, transparent and formalized structures of authority and 'democratic' in relation to the participatory mechanisms being set up. The democratic aspect of this outreach organization is necessary to discover the felt needs of a community and ensure success.

For Is'Baya, villagers show commitment by organizing a committee to liaise with the central organization. Roles are specified:

... a treasurer, a chairperson, a secretary, and what we call a liaison person. The liaison person was our contact. They had to have a cell phone. When they pay for their trees, the treasurer collects the money. We give them books ... books like this, and they must keep a record of it. Every household who paid their money.

An example of similar processes for TSURO is the selection of villagers as community facilitators. The first step is a village meeting of all adults. They select seven people to represent their village, including a chair person. The committee collects a fee from the villagers to gain membership of TSURO - US $\$ 10$ for their whole group. Then this committee attends a ward meeting with the members of other village committees, representing up to 15 villages. The ward meeting nominates three people who have $\mathrm{O}$ level (matriculation) and are known to work well with their communities as candidates for extension work with TSURO. Three wards all do this, making nine candidates in all. Each ward then sends its elected ward chair person to a joint meeting with the other chairs from the three wards and with the TSURO management team. This joint committee selects three candidates in total. KULIKA uses similar methods to call community meetings and find out what it is that communities need, before beginning their interventions. 
In Africa, a common strategy is to operate a project for a maximum of five years, with the intention that all projects should become self sustaining (Leahy 2009; Leach and Scoones 2006; Marais and Botes 2007; Ferguson 1994). This process almost always leads to projects failing after the professional staff leave. By constrast, all three of the food security outreach organizations nominate a set of clients and commit the organization for the long term.

Rose Du Preez from Is'Baya discussed the way large government bodies staffed by professionals expected to create and leave projects within a three year time frame:

They want to go in for two or three years and then they withdraw. I mean we've found that in Eastern Cape. And after two, three years they say, 'Okay, now we withdraw. We've given the people the technical knowledge so that they can carry on.' But it's not sustainable. They say, 'You've been there for ten years! Move onto another place.' And I say, 'Okay, show me one of your three year projects that's still working', and then they get quiet and they leave you alone. (laughs)

Is'Baya initially worked with fifteen villages in the Eastern Cape and this then expanded to 52 villages as other communities heard of their work and requested interventions. At this point Is'Baya refused to accept any more member villages. Instead they are concentrating on deepening their interventions in the villages where they are already working.

For the TSURO organization, the client base is defined as people of the Chimanimani district and more directly as villages, which become 'members' of the organization by paying a membership fee. Ulli Westermann explained the importance of continuity:

You have to be integrated in the community if you want to achieve anything. And you have to know the people. Its very difficult for outsiders to quickly jump in, do a quick two or three year program and then move on and phase out.

TSURO recruits long term professional staff and has a permanent central headquarters.

KULIKA also has permanent headquarters from which they manage their operations. Like TSURO, they recruit trained professionals to be the staff:

We select people who have back-up ground in environment, agricultural extension, agriculture, agriculture teachers. Then we bring them into our program and we train them as tutors.

So, a permanent organization manages outreach as well as liaison with international funding charities. This organization recruits a permanent professional staff, as well as some local extension workers. The organization engages beneficiaries as clients. As beneficiaries become effective in dealing with a problem there is less need for the 
outreach organization to be heavily involved. Nevertheless the NGO is available for support and will engage in new projects with the same clients.

\section{The Food Security Outreach model as 'Best Practice'}

It may seem audacious to claim the Food Security Outreach model as 'best practice' for rural food security projects in Southern Africa. The most we can really claim is that it deserves very serious consideration, further trials and more thorough validation. Nevertheless, we cite the following as indicative in the absence of a more thorough study.

We commissioned a survey of 25 TSURO beneficiary households (TSURO 2011). Most respondents had been involved with TSURO for more than eight years. More than 20 reported various kinds of food insufficiency before they joined TSURO. Their involvement with TSURO had helped them to grow more cereals ( 25 respondents), root crops (15), animal protein (20), vegetable protein (24), more vegetables (23) and more fruit (20). They also reported that they had been able to make some cash income to buy more food (20 respondents). Respondents also gave information about the assistance they had received. Eighteen mentioned instructions about more effective ways to farm, 20 had received assistance with materials to help construction, 19 had received assistance by being able to buy some supplies for their farm at a cheaper price. The technologies that had been introduced to more than 20 respondents were composting, growing vegetables at home and in the cropping fields, growing small livestock, woodlots and woodland preservation, stopping fires, mulching, and controlling larger livestock.

Probably the best evidence of the worth of the food security outreach model is the experience of the CELUCT project which preceded TSURO in the Chikukwa ward of the Chimanimani district (Goforth and Leahy 2011; Leahy and Leahy 2013). This project began in 1991 and is still going. It took in six villages with 7,000 people. CELUCT has been an embedded project, with the management team coming from the local village professional population (mostly teachers at local schools) along with other friends and neighbours. The problems faced by the Chikukwa villages were identical to those that the outreach projects are dealing with, and the strategies used are also the same. TSURO drew its inspiration from the success of CELUCT. This has been an astonishingly successful project with the landscape, food production and local culture being completely transformed.

Let us finish this paper by summarizing the characteristics of the food security outreach model:

In terms of the content of the assistance:

- The priority is food security via household subsistence

- Households are also encouraged to make some cash income from a surplus

- The agricultural strategy is low input farming

So all three of these projects make food security through household production their priority. At the same time, beneficiaries are encouraged to believe that the methods 
being suggested will in fact produce a surplus, over and above what the family needs for its own food security, and that this surplus can be sold. There is no doubt that some beneficiaries realize this cash income while almost all benefit greatly from the increase in household food provision. The key agricultural strategy is mixed farming with a minimal use of purchased inputs. The aim is to produce all nutritional needs and for the different parts of the farming enterprise to support each other. The stress on low cost organic solutions has the effect of enabling food security to be attained without the dangers of running short of cash to provide inputs.

In terms of the method of assistance:

- Individual households are the target

- No money is paid to beneficiaries to improve their own land

- All potential beneficiaries are invited

- Effective selection is by demonstrated commitment

- Few material inputs - the most important assistance is educational

- Bureaucratic democracy links beneficiaries and the organization

- The donor organization maintains an ongoing relationship with its clients

The method of assistance is just as crucial for the success of these projects. Crucially, these projects do not attempt to join households together to realize a common profit and to depend on this to maintain their collective enterprise. Instead they are directed firstly at improving the productivity of individual households on their own land. As we have seen this does not rule out various kinds of community organisation to facilitate this household production. These organisations resist competitive pressure from projects which pay beneficiaries for work. In the food security outreach projects, people are never paid to work on their own land or on the community land. Projects may start very small because they begin with people who are willing to volunteer their own work to improve their own production. They grow as the success of the approach being promoted becomes evident. Because food security outreach projects do not attempt to set up commercial farming operations, the cost of donations of materials to individual households remains very minimal. It becomes possible for the project to be offered to all the households in a residential district. There is no exclusion, no community jealousy and the project does not proceed by picking winners. On the other hand, successful beneficiaries may be rewarded by having their households chosen to represent best practice and get a small payment for farmer to farmer visits to their site. Transparency and a degree of control by the beneficiaries is achieved through various kinds of representation and democratic organisation. The logic is that interventions can only work if local people believe that they meet a felt need. Finally, none of these organisations works through a model in which an intervention is carried out for several years and then project staff withdraw. Instead, the project team has an ongoing relationship with a set of clients. Interventions build on previous interactions. At a certain point in time, the food security outreach project will stop expanding and will restrict itself to a particular set of clients that can be handled effectively. Ideally, it inspires people from other districts or countries to receive training and set up their own similar organisation.

We are suggesting that this model may well be best practice for food security projects in rural Southern and South Eastern Africa. In the absence of more definitive 
evidence we are arguing that it should certainly be tried out thoroughly in areas where current project designs have not had a great deal of long term impact.

\section{References}

Alinyo, F. and T. Leahy. 2012. "Designing food security projects:

Kapchorwa and Bukwo, Uganda." Development in Practice 22 (3): 334-346.

Barkworth, C. and C. Harland. 2009. Zambia: Situational Analysis of Women and Children 2008, Lusaka, Zambia: The United Nations Children's Fund.

Bryceson, D. 2000. "Rural Africa at the crossroads: Livelihood practices and policies.” Natural Resource Perspectives 52, London: Overseas Development Institute. Accessed 5 January 2006. http://www.odi.org.uk/nrp/52.html

Chipeta, S. Christoplos, I. and E. Katz. 2008. Common Framework on MarketOriented Agricultural Advisory Services, Neuchatel Group, Swiss Centre for Agricultural Extension and Rural Development (AGRIDEA), Lindau, Switzerland.

Danida. 2005. A Joint Evaluation: Uganda's Plan for the Modernisation of Agriculture, Ministry of Foreign Affairs, Denmark: Oxford Policy Management Limited.

De Janvry, A. and E. Sadoulet. 2011. "Subsistence farming as a safety net for foodprice shocks." Development in Practice 21 (4-5): 472-480

Department of Agriculture. 2002. Integrated Food Security Strategy. Pretoria: Department of Agriculture. Accessed 14 July 2008. http://www.nda.agric.za

FARA. 2006. Framework for African Agricultural Productivity, Accra, Ghana: Forum for Agricultural Research in Africa.

Ferguson, J. 1994. The Anti-Politics Machine: 'Development,' Depoliticization, and Bureaucratic Power in Lesotho. Cambridge: Cambridge University Press.

Goforth, M. and T. Leahy. 2011. "Permaculture successes in a Zimbabwean community." Permaculture Institute. Accessed 16 March 2012. http://permaculture.org.au/2011/10/01/permaculture-successes-in-a-zimbabweancommunity/

Japan Association. 2008. The Maize in Zambia and Malawi. Tokyo: Japan Association for International Collaboration of Agriculture and Forestry.

Jones, P. and R. DuPreez. 2008. Integrated Village Renewal Programme: A comprehensive multi-year development programme for rural villages, Mthatha: Is'Baya Development Trust and Nelspruit: Agricultural Research Council Institute for Tropical and Subtropical Crops.

Leach, M. and I. Scoones. 2006. The Slow Race: Making Technology Work for the Poor, London: Demos. 
Kulika. 2009. "Kulika Uganda Since 1981 Annual Report 2009.” Kampala: Kulika.

Leahy, T. 2009. Permaculture Strategy for the South African Villages, Palmwoods, Queensland: PI Productions.

Leahy, T. 2011. "Teaching them to fish: Entrepreneurial ideology and rural projects in South Africa." South African Review of Sociology 42 (1): 37-57.

Leahy, G. and T. Leahy. 2013. "The Chikukwa project", Accessed 31 December 2013. www.thechikukwaproject.com

Leavy, J. and C. Poulton. 2007. 'Commercializations in Agriculture', Future Agricultures, Working paper 003. Accessed 18 December 2012. www.futureagricultures.org

MAAIF. 2000. Plan for Modernisation of Agriculture: Eradicating Poverty in Uganda, Kampala, Uganda: Ministry of Agriculture, Animal Industry and Fisheries, Ministry of Finance, Planning and Economic Development.

Magadzi, D. 2008. Limpopo Department of Agriculture Budget Speech 2008/09. South African Government Information. Accessed 28 November 2010. http://www.info.gov.za/speeches/2008/08052816451002.htm

Marais, L. and L. Botes. 2007. "Income generation, local economic development and community development: Paying the price for lacking business skills?" Community Development Journal 42 (3): 379-395.

Marenya, P. P. and C. B. Barrett. 2007. "Household-level determinants of adoption of improved natural resources management practices among smallholder farmers in western Kenya." Food Policy 32: 5151-536.

Maxwell, S. and A. Fernando. 1989. "Cash crops in developing countries: The issues, the facts, the policies." World Development 17 (11): 1677 - 1708.

Mollison, B. 1988. Permaculture: A Designers' Manual, Tyalgum, Australia: Tagari Publications.

Payer, C. 1979. “The modernisation game.” New Internationalist 081

Phiria, D., Franzelb, S., Mafongoyac, P., Jered, I., Katangac, R. and S. Phiric. 2004. "Who is using the new technology? The associations of wealth, status and gender with the planting of improved tree fallows in Eastern Province, Zambia." Agricultural Systems 79: 131-144.

Pretty, J. 1995. Regenerating Agriculture: Policies and Practice for Sustainability and Self-reliance, Washington, DC:Joseph Henry Press.

Rural Poverty Portal 2012. “Land: Statistics.”, Accessed 31 May, 2012. 
http://www.ruralpovertyportal.org/web/guest/topic/statistics/tags/land

Shackleton, C.M., Shackleton, S.E., and B. Cousins 2001. "The role of land-based strategies in rural livelihoods: the contribution of arable production, animal husbandry and natural resource harvesting in communal areas in South Africa." Development Southern Africa 18 (5): 581 - 604.

Timmer, P.C. 2005. "Agriculture and pro-poor growth: An Asian perspective." Working Paper Number 63, Washington, DC: Center for Global Development.

Tschirley, D.L. and S. Kabwe 2007. "Cotton in Zambia: 2007 Assessment of its organization, performance, current policy initiatives, and challenges for the future." Working Paper No. 26, Food Security Research Project, Lusaka, Zambia. Accessed 19 Dec 2012. http://www.aec.msu.edu/agecon/fs2/zambia/index.htm

TSURO 2011. "TSURO Trust Survey Report." Unpublished paper compiled by M. Samoko and T. Samushonga, Sept 5-9, Chimanimani, Zimbabwe: TSURO.

Webersik, C. and C. Wilson 2008. "Achieving environmental sustainability and growth in Africa: the role of science, technology and innovation." Sustainable Development 17: 400-413.

Williams, G. 1996. "Setting the agenda: A critique of the World Bank's restructuring programme for South Africa.” Journal of Southern African Studies, (22)1: 139-167.

Wolter, D. 2008. "Tanzania: The challenge of moving from subsistence to profit." OECD Development Centre. Accessed 18 December 2012. www.oecd.org

Wright, S. 2008. "Practising hope: Learning from social movement strategies in the Phillipines." In Fear:Critical Geopolitics and Everyday Life", edited by R.Pain and S. J. Smith, Farnham, UK: Ashgate. 